\title{
X-linked myotubular myopathy
}

\section{A prospective international natural history study}

\author{
Mélanie Annoussamy, PhD, Charlotte Lilien, Teresa Gidaro, MD, PhD, Elena Gargaun, MD, Virginie Chê, \\ Ulrike Schara, MD, Andrea Gangfuß, MD, Adele D’Amico, MD, James J. Dowling, MD, Basil T. Darras, MD, \\ Aurore Daron, MD, Arturo Hernandez, MD, PhD, Capucine de Lattre, MD, Jean-Michel Arnal, MD, \\ Michèle Mayer, MD, Jean-Marie Cuisset, MD, Carole Vuillerot, MD, Stéphanie Fontaine, MD, \\ Rémi Bellance, MD, Valérie Biancalana, PhD, Ana Buj-Bello, MD, PhD, Jean-Yves Hogrel, PhD, Hal Landy, MD, \\ and Laurent Servais, MD, PhD
}

Neurology ${ }^{\circledR}$ 2019;92:e1852-e1867. doi:10.1212/WNL.0000000000007319

\section{Abstract \\ Objectives}

Because X-linked myotubular myopathy (XLMTM) is a rare neuromuscular disease caused by mutations in the MTM1 gene with a large phenotypic heterogeneity, to ensure clinical trial readiness, it was mandatory to better quantify disease burden and determine best outcome measures.

\section{Methods}

We designed an international prospective and longitudinal natural history study in patients with XLMTM and assessed muscle strength and motor and respiratory functions over the first year of follow-up. The humoral immunity against adeno-associated virus serotype 8 was also monitored.

\section{Results}

Forty-five male patients aged 3.5 months to 56.8 years were enrolled between May 2014 and May 2017. Thirteen patients had a mild phenotype (no ventilation support), 7 had an intermediate phenotype (ventilation support less than 12 hours a day), and 25 had a severe phenotype (ventilation support 12 or more hours a day). Most strength and motor function assessments could be performed even in very weak patients. Motor Function Measure 32 total score, grip and pinch strengths, and forced vital capacity, forced expiratory volume in the first second of exhalation, and peak cough flow measures discriminated the 3 groups of patients. Disease history revealed motor milestone loss in several patients. Longitudinal data on 37 patients showed that the Motor Function Measure 32 total score significantly decreased by $2 \%$. Of the 38 patients evaluated, anti-adeno-associated virus type 8 neutralizing activity was detected in $26 \%$ with 2 patients having an inhibitory titer $>1: 10$.

\section{Conclusions}

Our data confirm that XLMTM is slowly progressive for male survivors regardless of their phenotype and provide outcome validation and natural history data that can support clinical development in this population.

\section{ClinicalTrials.gov identifier NCT02057705.}

\author{
Correspondence \\ Prof. Servais \\ I.servais@ \\ institut-myologie.org
}




\section{Glossary}

AAV = adeno-associated virus; CHOP-INTEND = Children's Hospital of Philadelphia Infant Test of Neuromuscular Disorders; FEV1 = forced expiratory volume in the first second of exhalation; FVC = forced vital capacity; MEP = maximum expiratory pressure; $\mathbf{M F M}=$ Motor Function Measure; MHFMS = Modified Hammersmith Functional Motor Scale; MIP = maximum inspiratory pressure; NSAA = North Star Ambulatory Assessment; PCF = peak cough flow; XLMTM = X-linked myotubular myopathy.

X-linked myotubular myopathy (XLMTM, OMIM 310400) is a rare disease of skeletal muscle affecting approximately 1 in 50,000 male newborns. ${ }^{1}$ XLMTM is caused by mutations in the MTM1 gene, which encodes the ubiquitous phosphatase myotubularin. Myotubularin is implicated in the phosphatidylinositol 3-kinase pathway that regulates intracellular membrane trafficking and vesicular transport processes. $^{2-6}$

Patients with XLMTM are classified as having mild, intermediate, or severe phenotype based on the amount of ventilator support required. ${ }^{7}$ Much milder phenotypes have also been described. ${ }^{8,9}$ Most patients have the severe form ${ }^{10,11}$ and typically present at birth with severe hypotonia and inability to establish spontaneous respiration, often leading to death within the first months of life. Long-term survivors with the severe phenotype are often nonambulant and need ventilation support. ${ }^{10,12}$ Patients with the intermediate and mild phenotypes breathe independently at least a few hours per day, and become ambulant. ${ }^{7,12,13}$ Among comorbidities, liver abnormalities are often reported. ${ }^{10-12}$

Several therapeutic strategies are under investigation including gene therapy (NCT03199469), ${ }^{14,15}$ enzyme replacement therapy, ${ }^{16}$ dynamin-2 modulation, ${ }^{17,18}$ and PIK3C2B inhibition. ${ }^{19}$ To ensure clinical trial readiness and to better quantify disease burden in patients with XLMTM, we designed an international prospective and longitudinal natural history study to assess muscle strength and pulmonary and motor function using standardized measures. We also tested for the presence of neutralizing antibodies against adeno-associated virus (AAV) type 8 in serum, as humoral immune response to AAV can prevent $\mathrm{AAV}$ vector transduction. ${ }^{20,21}$

\section{Methods}

\section{Patients and study design}

We conducted an international, multicenter, prospective, and longitudinal study on patients with XLMTM (NatHis-MTM) sponsored by Valerion Therapeutics, LLC (Concord, MA). This 3-year study was performed at 14 investigational sites located in the United States, Canada, France, Spain, Italy, Germany, and Belgium. All patients with XLMTM, males and symptomatic females, not treated with an experimental therapy other than pyridostigmine and not having another disease that might substantially interfere with XLMTM assessments, were allowed to take part in this study with no restrictions on age. This report focuses on the data obtained on male patients over a 1-year period.

Patients younger than 2 years were assessed quarterly, patients aged between 2 and 6 years were assessed every 6 months, and older patients were assessed every 6 months during the first year and annually thereafter. Depending on the enrollment date, patient participation lasted between 12 and 36 months. Disease history, psychomotor development, cardiac, respiratory, liver, kidney, coagulation, and hematologic functions, and feeding and orthopedic status were obtained from the available medical files and patient/parent interviews. A standard liver ultrasound was performed every year and serum chemistries were collected from the available medical files. A 24-hour urine collection every 6 months measured the amount of creatinine excreted as a marker of the skeletal muscle mass. ${ }^{22}$ At each visit, the physician performed a complete physical examination, noted concomitant treatments and adverse events, measured vital signs, weight and height, and assessed ophthalmoplegia and ptosis. Likewise, at each visit, certified physiotherapists assessed motor function, upper limb strength, and respiratory function. These standardized evaluations were adjusted according to age, ambulatory status, and respiratory support needed.

Grip and pinch strength were assessed with the MyoGrip and MyoPinch devices in patients older than 6 years, as previously described. ${ }^{23}$ To limit fatigue, patients were tested only on the dominant side. Results are expressed as percent of predicted values based on age using predictive equations constructed with normative data aggregated at the Institute of Myology:

For patients aged 6 to 16 years:

Grip strength $=$ Grip $\times 100 / 3.3996 \times \operatorname{EXP}(0.1527 \times$ age $)$

Pinch strength $=$ Pinch $\times 100 / 1.9647 \times \operatorname{EXP}(0.0828 \times$ age $)$

For patients 17 years and older:

Grip strength $=$ Grip $\times 100 / 45.662 \times \operatorname{EXP}(-0.001 \times$ age $)$

Pinch strength $=$ Pinch $\times 100 / 7.98 \times \operatorname{EXP}(-0.001 \times$ age $)$

Patients older than 6 years without tracheostomy underwent pulmonary function tests measuring forced vital capacity (FVC), forced expiratory volume in the first second of exhalation $\left(\mathrm{FEV}_{1}\right)$, peak cough flow (PCF), and maximum 
expiratory and inspiratory pressure (MEP and MIP). FVC, $\mathrm{FEV}_{1}$, and PCF were measured using the Vitalograph spirometer and software (Lenexa, KS). MEP and MIP were captured using the MicroRPM device. Results are expressed as percent of predicted values using previously published equations based on age and height. ${ }^{24-26}$ Percentage of FVC and $\mathrm{FEV}_{1}$ were computed using a calculator (biostat.jhsph. $\mathrm{edu} /$ courses $/$ bio622/misc/calculate.htm) based on information presented in ref. 24 .

To assess motor function, children younger than 2 years of age performed the Children's Hospital of Philadelphia Infant Test of Neuromuscular Disorders (CHOP-INTEND) scale ${ }^{27}$ and the Modified Hammersmith Functional Motor Scale (MHFMS). ${ }^{28}$ For safety reasons, the last 2 items of the CHOP-INTEND were not performed. Patients older than 2 years of age performed the Motor Function Measure (MFM) 29 scale. Children aged from 2 to 5 years performed the MHFMS and short version of MFM (20 items vs 32). Patients turning 6 years of age during the study continued to be evaluated with the MFM20. ${ }^{30}$ Patients older than 6 years performed the MFM32, and their dominant upper limb motor function was assessed by the MoviPlate device, as previously described. ${ }^{23}$ Ambulant patients older than 6 years performed the North Star Ambulatory Assessment (NSAA) scale and timed tests including 6-minute walk distance, 10-m run/walk (NSAA, item 17), and time to rise from floor (NSAA, item 11), as previously described ${ }^{31-33}$

Patients were given 2 attempts to perform testing with MoviPlate and 3 attempts to measure grip and pinch strength and each pulmonary function. If they continuously improved, further tests were conducted until patients achieved their best result, which was retained for statistical analysis.

We used the Patient Reported Outcomes Measurement Information System Short Form Instruments for Open Distribution to assess the patients' quality of life and asked 3 questions on the number of social events, work, or school days missed because of XLMTM.

All assessments were administered according to standardized procedures. The same physiotherapist assessed patients in France, Italy, and Spain. She fully trained Belgian and German physiotherapists and assisted them during first assessments. Assessments in North America were performed by physiotherapists trained at an organized session by the European physiotherapist. Study monitors regularly evaluated protocol and Good Clinical Practice compliance as well as quality, completeness, and consistency of the data collected in the case report forms at all sites.

The neutralizing antibody assay on serum samples of patients was performed using the GenoSafe procedure. Briefly, HEK293T cells were plated on day 1 in 96-well plates and were allowed to rest for $24 \pm 1$ hour at $35^{\circ} \mathrm{C}$ to $38^{\circ} \mathrm{C}$ in $5 \%$ $\mathrm{CO}_{2}$ before transduction. After serial dilution (1:1-1:405) in normal seronegative human pooled serum, dilutions and quality controls were incubated together with a recombinant AAV8-CMV-luciferase vector for 1 hour \pm 15 minutes at $35^{\circ} \mathrm{C}$ to $38^{\circ} \mathrm{C}$. AAV8 transduction inhibition titers were determined as the reciprocal dilution of plasma interpolated at the titer cut point set at $61.60 \%$ of transduction.

\section{Standard protocol approvals, registrations, and patient consents}

This study was approved by local ethics/institutional review boards and the French health authority (ANSM) and was registered on clinicaltrials.gov (NCT02057705). All enrolled patients (or parents for patients younger than 18 years) signed an informed consent before any study-related procedure.

\section{Statistical analyses}

Statistical analyses were performed following a prespecified statistical analysis plan. Mild, intermediate, and severe phenotypes were prespecified for comparison analysis. Characteristics of the 3 groups were computed by descriptive analyses. To determine outcome measures able to differentiate patients with different disease levels, proportions were compared using the $\chi^{2}$ test and quantitative variables using the Kruskal-Wallis 1-way analysis of variance. Post hoc tests based on the Dunn-Bonferroni method were performed in case of significance. Correlation between creatinuria excreted in 24 hours and standardized assessments for muscle strength and pulmonary and motor functions were assessed with the Spearman correlation coefficient. Changes over time were assessed using a Wilcoxon signed-rank test. All analyses were performed using SPSS Statistics 22 statistical software (IBM Corp., Armonk, NY). The limit of statistical significance was set to 0.05 .

\section{Data availability}

Deidentified participant data are available on request.

\section{Results}

\section{Patient characteristics}

\section{Demographics}

Forty-five male patients from 3.5 months to 56.8 years of age were enrolled between May 2014 and May 2017 (figure 1A). Nine patients were enrolled in North America ( 5 in Canada, 4 in the United States) and 36 in Europe (15 in France, 10 in Germany, 7 in Italy, 2 in Spain, and 2 in Belgium). At inclusion, $27 \%$ of patients were younger than 2 years old, $20 \%$ were aged between 2 and 5 years, and 53\% were 6 years or older (table 1).

\section{Clinical characteristics at baseline}

Twenty-nine percent of patients presented with a mild phenotype, $16 \%$ with an intermediate phenotype, and 55\% with a severe phenotype (figure $1 \mathrm{~A}$ and table 1 ). All patients, including patients with a mild phenotype had abnormal 
Figure 1 Patient flowchart and mutations detected in the MTM1 gene

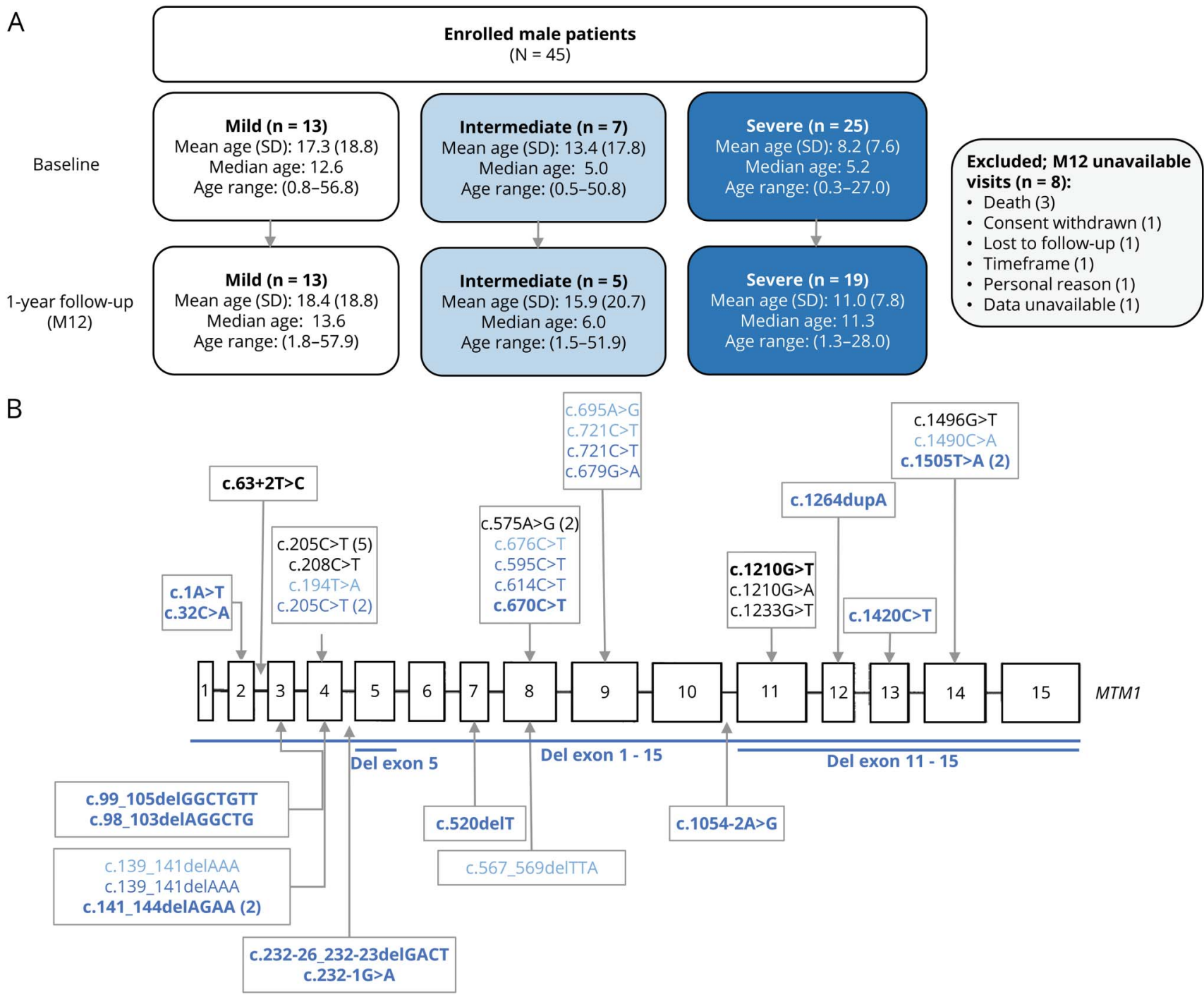

(A) Patient flowchart. Age is expressed in years. (B) Mutations detected in the MTM1 gene. Mutations written in black, light blue, and dark blue correspond to mild, intermediate, and severe phenotype, respectively. Mutations predicted to be linked to reduction or absence of functional protein are indicated in bold (frameshift, nonsense, splicing, in-frame exon deletion, large deletion, and start codon loss). A protein with residual function may be present for missense mutations and in-frame small deletions. Numbers in parentheses are number of patients with the same mutation and phenotype.

pulmonary function with FVC, $\mathrm{FEV}_{1}, \mathrm{MEP}, \mathrm{MIP}$, and PCF lower than $80 \%$ of normal. FVC, $\mathrm{FEV}_{1}$, and PCF were the most different parameters between patient groups (table 2 and figure 2). Motor function as assessed by MFM and distal muscle strength as assessed by MyoGrip and MyoPinch were also abnormal in all groups with a strong group effect toward lower values in the intermediate and severe phenotypes. Distal muscle weakness was correlated with reduced muscle mass as assessed by the 24-hour excreted creatinuria (Spearman coefficient of 0.727 and 0.656 for grip and pinch strength, respectively) (figure 3 and table 2 ).

Scoliosis was present in $60 \%$ of patients and was more frequently encountered in patients with the severe phenotype ( $p$ $=0.007$ ). Four patients required spinal surgery before the study. The angle of scoliosis was less than $30^{\circ}$ for 12 of the 19 remaining patients. Contractures were also more frequent in patients with the severe phenotype but the difference did not reach statistical significance ( $64 \%$ vs $43 \%$ and $38 \%$ in the intermediate and mild phenotypes, respectively; $p=0.118$ ).

Eighty-nine percent of patients reported feeding difficulties mainly characterized by swallowing, sucking, and chewing difficulties (76\%, 58\%, and 56\%, respectively), and $76 \%$ of patients had feeding tubes (16\% nasogastric tube, $60 \%$ gastrostomy) (table 1). Gastrostomies were more frequent in patients with severe phenotype ( $84 \%$ vs $57 \%$ and $23 \%$ in the intermediate and mild phenotypes, respectively; $p=0.005$ ) (table 1).

Ophthalmoplegia and ptosis were common in all phenotypes and present in $96 \%$ and $78 \%$ of patients, respectively. 


\section{Table 1 Patient characteristics}

\begin{tabular}{|c|c|c|c|c|c|c|c|c|c|}
\hline Patient no. & $\begin{array}{l}\text { Age at } \\
\text { inclusion, y }\end{array}$ & $\begin{array}{l}\text { Weight, }^{a} \\
\text { percentile }\end{array}$ & $\begin{array}{l}\text { Length/height, }{ }^{a} \\
\text { percentile }\end{array}$ & $\begin{array}{l}\text { Mutation (NM_ } \\
000252.2)\end{array}$ & Predicted effect & $\begin{array}{l}\text { Ambulatory } \\
\text { status }\end{array}$ & $\begin{array}{l}\text { Breathing } \\
\text { support }\end{array}$ & $\begin{array}{l}\text { Feeding } \\
\text { support }\end{array}$ & $\begin{array}{l}\text { AAV8 } \\
\text { inhibitory } \\
\text { titer }\end{array}$ \\
\hline \multicolumn{10}{|c|}{$\begin{array}{l}\text { Mild (i.e., no ventilation } \\
\text { support) }\end{array}$} \\
\hline $1^{b}$ & 0.8 & $<1$ & 37.7 & c. $1210 \mathrm{G}>\mathrm{T}$ & p.(Glu404*) & NA & None & NGT & $<1$ \\
\hline $2^{b}$ & 1.7 & 21.2 & 92.4 & c. $205 C>T$ & p.(Arg69Cys) & NA & None & PEG & 27.51 \\
\hline $3^{b}$ & 4.2 & 16.4 & 76.9 & c. $205 C>T$ & p.(Arg69Cys) & A & None & None & $<1$ \\
\hline $4^{b}$ & 4.9 & 14.7 & 52.3 & c. $63+2 T>C$ & Destruction donor splice site exon 2 & NA & None & NGT & $<1$ \\
\hline $5^{b}$ & 6.5 & 29.1 & 92.5 & c. $205 C>T$ & p.(Arg69Cys) & A & None & None & $<1$ \\
\hline $6^{\mathrm{b}}$ & 7.7 & 28.8 & 85.9 & c. $205 C>T$ & p.(Arg69Cys) & A & None & None & 3.91 \\
\hline $7^{b}$ & 12.6 & 4.5 & 32.9 & c. $1210 \mathrm{G}>\mathrm{A}$ & p.(Glu404Lys) & A & None & None & $<1$ \\
\hline $8^{b}$ & 13.7 & 19.2 & 17.9 & c. $205 C>T$ & p.(Arg69Cys) & NA & None & PEG & $<1$ \\
\hline $9^{b}$ & 14 & 3.1 & 50.1 & c. $575 \mathrm{~A}>\mathrm{G}$ & p.(Tyr192Cys) & A & None & None & $<1$ \\
\hline $10^{b}$ & 15.3 & 19.3 & $<1$ & c. $1496 \mathrm{G}>\mathrm{T}$ & p.(Trp499Leu) & $A$ & None & PEG & 8.49 \\
\hline $11^{b}$ & 33.7 & 2.1 & 25 & c. $1233 \mathrm{G}>\mathrm{T}$ & p.(Trp411Cys) & A & None & None & $<1$ \\
\hline $12^{b}$ & 53.4 & 98.3 & 90.1 & c. $208 C>T$ & p.(Leu71Phe) & A & None & None & $<1$ \\
\hline $13^{b}$ & 56.8 & 90.1 & 42.5 & c. $575 A>G$ & p.(Tyr192Cys) & $A$ & None & None & $<1$ \\
\hline \multicolumn{10}{|c|}{$\begin{array}{l}\text { Intermediate (i.e., ventilation } \\
\text { support }<12 \mathrm{~h} / \mathrm{d} \text { ) }\end{array}$} \\
\hline $14^{\mathrm{b}}$ & 0.5 & $<1$ & 9.8 & c. $1490 C>A$ & p.(Ser497Tyr) & NA & NIV: $10 \mathrm{~h}$ & PEG & $<1$ \\
\hline 15 & 1.2 & 0.3 & 96.4 & c.721C $>\mathrm{T}$ & p.(Arg241Cys) & NA & IV: $10 \mathrm{~h}$ & PEG & $<1$ \\
\hline $16^{b}$ & 3.9 & 6 & 79.9 & c.567-569delTAA & p.(Asn189del) & NA & IV: $8 \mathrm{~h}$ & PEG & $<1$ \\
\hline $17^{b}$ & 5 & 1.4 & 72.7 & c.139_141delAAA & p.(Lys47del) & NA & NIV: $10 \mathrm{~h}$ & PEG & $<1$ \\
\hline $18^{\mathrm{b}}$ & 14.2 & 59.7 & 62.4 & c. $676 C>T$ & p.(Pro226Ser) & NA & NIV: $8 \mathrm{~h}$ & NGT & $<1$ \\
\hline 19 & 18.4 & 29.8 & 80.7 & c. $695 \mathrm{~A}>\mathrm{G}$ & p.(His232Arg) & NA & NIV: $8 \mathrm{~h}$ & NGT & 4.1 \\
\hline $20^{b}$ & 50.8 & 92.9 & 56.4 & c.194T>A & p.(Ile65ASN) & A & NIV: $10 \mathrm{~h}$ & None & $>405$ \\
\hline
\end{tabular}




\section{Table 1 Patient characteristics (continued)}

\begin{tabular}{|c|c|c|c|c|c|c|c|c|c|}
\hline Patient no. & $\begin{array}{l}\text { Age at } \\
\text { inclusion, y }\end{array}$ & $\begin{array}{l}\text { Weight, }{ }^{a} \\
\text { percentile }\end{array}$ & $\begin{array}{l}\text { Length/height, a } \\
\text { percentile }\end{array}$ & $\begin{array}{l}\text { Mutation (NM_ } \\
\text { 000252.2) }\end{array}$ & Predicted effect & $\begin{array}{l}\text { Ambulatory } \\
\text { status }\end{array}$ & $\begin{array}{l}\text { Breathing } \\
\text { support }\end{array}$ & $\begin{array}{l}\text { Feeding } \\
\text { support }\end{array}$ & $\begin{array}{l}\text { AAV8 } \\
\text { inhibitory } \\
\text { titer }\end{array}$ \\
\hline
\end{tabular}

Severe (i.e., ventilation

support $\geq 12 \mathrm{~h} / \mathrm{d}$ )

\begin{tabular}{|c|c|c|c|c|c|c|c|c|c|}
\hline $21^{b}$ & 0.3 & $<1$ & 71.5 & $\begin{array}{l}\text { c.99- } \\
105 \overline{d e l G G C T G T T ~}\end{array}$ & p.(Glu33Aspfs*9) & NA & IV: $20 \mathrm{~h}$ & PEG & 3.71 \\
\hline 22 & 0.8 & 4.3 & 90 & c. $1054-2 A>G$ & Destruction acceptor splice site exon 11 & NA & IV: $24 \mathrm{~h}$ & PEG & $<1$ \\
\hline $23^{b}$ & 1.3 & 89 & 91.4 & c. $670 \mathrm{C}>\mathrm{T}$ & p. $\left(\operatorname{Arg} 224^{*}\right)$ & NA & IV: $24 \mathrm{~h}$ & PEG & UNK \\
\hline 24 & 1.6 & 9.7 & 88.6 & c. $614 C>T$ & p.(Pro205Leu) & NA & IV: $24 \mathrm{~h}$ & PEG & UNK \\
\hline $25^{b}$ & 1.6 & 20.9 & $>99$ & c. $1505 T>A$ & p.(lle502Lys) & NA & IV: $24 \mathrm{~h}$ & PEG & $<1$ \\
\hline $26^{b}$ & 1.6 & 29.2 & $>99$ & c. $1505 \mathrm{~T}>\mathrm{A}$ & p.(lle502Lys) & NA & IV: $24 \mathrm{~h}$ & PEG & $<1$ \\
\hline 27 & 1.7 & 67 & $>99$ & c. $205 C>T$ & p.(Arg69Cys) & NA & IV: $18 \mathrm{~h}$ & PEG & UNK \\
\hline 28 & 1.9 & 56.9 & 99.6 & c. $32 \mathrm{C}>\mathrm{A}$ & p.(Ser11*) & NA & IV: $24 \mathrm{~h}$ & PEG & UNK \\
\hline $29^{b}$ & 2.2 & 0.5 & 96.9 & c.141-144delAGAA & p.(Glu48Leufs*24) & NA & IV: $24 \mathrm{~h}$ & PEG & $<1$ \\
\hline 30 & 2.3 & 6.7 & 91.7 & Deletion all MTM1 & Deletion all MTM1 & NA & IV: $24 \mathrm{~h}$ & PEG & UNK \\
\hline $31^{b}$ & 2.6 & 36.5 & 98.5 & $\begin{array}{l}\text { c.98- } \\
\text { 103delAGGCTG }\end{array}$ & p.(Glu33_Ala34del) & NA & IV: $24 \mathrm{~h}$ & PEG & $<1$ \\
\hline $32^{b}$ & 4.7 & 55.9 & $>99$ & c. $1 \mathrm{~A}>\mathrm{T}$ & p. $?^{x}$ & NA & IV: $23 \mathrm{~h}$ & PEG & 3.25 \\
\hline $33^{b}$ & 5.2 & 50.9 & 82.9 & c.1264dupA & p.(lle422Asnfs*5) & NA & IV: $16 \mathrm{~h}$ & PEG & $<1$ \\
\hline 34 & 6.6 & 48.5 & 80 & c. $679 \mathrm{G}>\mathrm{A}$ & p.(Val227Met) & NA & IV: $24 \mathrm{~h}$ & PEG & $<1$ \\
\hline $35^{\mathrm{b}}$ & 7.1 & 22.9 & 65.5 & Exon 5 deletion ${ }^{d}$ & Exon 5 deletion & NA & IV: $12 \mathrm{~h}$ & PEG & $<1$ \\
\hline $36^{b}$ & 10.3 & 4.6 & 21.8 & $\begin{array}{l}\text { Deletion exons } \\
11-15^{d}\end{array}$ & Deletion exons 11-15 & NA & IV: $24 \mathrm{~h}$ & PEG & $<1$ \\
\hline $37^{b}$ & 11.8 & 36 & 72.6 & c. $205 C>T$ & p.(Arg69Cys) & NA & IV: $24 \mathrm{~h}$ & PEG & 2.69 \\
\hline $38^{b}$ & 12.3 & 48.7 & 55.4 & c.595C>T & p.(Pro199Ser) & NA & NIV: $13 \mathrm{~h}$ & None & $<1$ \\
\hline $39^{b}$ & 13.6 & 41.4 & 70.5 & c. $232-1 \mathrm{G}>\mathrm{A}$ & Destruction acceptor splice site exon 5 & NA & IV: $24 \mathrm{~h}$ & PEG & UNK \\
\hline $40^{b}$ & 15 & $<1$ & $<1$ & c. $1420 C>T$ & p.(Arg474*) & NA & IV: $24 \mathrm{~h}$ & PEG & $<1$ \\
\hline $41^{b}$ & 15.8 & 41 & 40.2 & c.139_141delAAA & p.(Lys47del) & NA & IV: $24 \mathrm{~h}$ & None & $<1$ \\
\hline
\end{tabular}




\section{Genotype/phenotype correlation}

The 45 mutations detected were distributed throughout the MTM1 gene. Mutations were mainly missense (53.3\%) and in-frame small deletions (8.9\%) that may be compatible with a residual normal function of the protein. Those mutations represent $90 \%$ of the mutations in the mild and intermediate groups but only $40 \%$ in the severe group. The remaining $37.8 \%$ of mutations are predicted to result in reduction or absence of functional protein (frameshift, nonsense, splicing, in-frame exon deletion, large deletion, and start codon loss) and were mainly present in the severe group (figure 1B).

\section{History of the disease}

Hypotonia and respiratory distress were common at birth (43/45 and $41 / 45)$, requiring breathing support in $82 \%$ of patients and leading to long hospital stays during the first year of life. The median hospital stays were 22,75 , and 142 days for the mild, intermediate, and severe groups, respectively. Breathing support duration at birth was longest in the severe group. Nevertheless, independent breathing occurred in 31 of 45 patients shortly after birth and was secondarily lost in 9 patients in the severe group at the median age of 6 months (figure 4).

Motor milestones acquired by most of the patients included the ability to bring hand to mouth, independent head control, and the abilities to roll on one side and to sit independently when placed in a sitting position. Milestone acquisitions were delayed and previously acquired milestones were secondarily lost mostly in patients with the severe phenotype (figure 4).

In addition, 30 patients reported at least one episode of lower respiratory tract infection. Physicians reported contracture in 25 patients, areflexia in 13, high arched palate in 11, and chest dysmorphism in 5 patients. Severe patients were often affected by cryptorchidism $(17 / 25)$ and phimosis $(5 / 25)$. Three patients reported cholelithiasis and 5 nephrolithiasis. Conduction and heart rhythm abnormalities were reported in 5 and 7 patients, respectively. Seven had abnormal heart structure (ventricular hypertrophy, patent foramen ovale, and ventricular septal defect). Episodes of abnormal bleeding were reported in 7 patients, abnormal clotting in 2 patients, anemia in 9 patients, and thrombocytopenia and hypertension in 5 patients. Hepatomegaly was observed in 4 patients; steatosis, hyperechogenicity, and hepatic cysts in 3 patients; and portal and hepatic vessel modification in one patient. No intellectual disabilities were reported.

\section{Disease burden}

A feeding tube was used by $82 \%$ of patients (table 1). Sixtynine percent of patients older than 2 years of age were nonambulant and required assistive devices such as manual or powered wheelchairs, standers, orthotics, or splints. Sixtyeight percent of patients with scoliosis needed a corset or a lumbar belt. The number of hospitalizations normalized by the life-year number varied between 0.1 and 4.2 with a median number of 0.8 . The total duration of hospitalization was 


\begin{tabular}{|c|c|c|c|c|c|c|c|c|c|}
\hline & \multicolumn{2}{|c|}{ All $(n=45)$} & \multicolumn{2}{|c|}{ Mild $(n=13)$} & \multicolumn{2}{|c|}{ Intermediate $(\mathrm{n}=7)$} & \multicolumn{2}{|c|}{ Severe $(n=25)$} & \multirow[b]{2}{*}{ Phenotype effect, $p$ value } \\
\hline & No. & Median (min-max) & No. & Median (min-max) & No. & Median (min-max) & No. & Median (min-max) & \\
\hline Age, y & 45 & $6.6(0.3-56.8)$ & 13 & $12.6(0.8-56.8)$ & 7 & $5.0(0.5-50.8)$ & 25 & $5.2(0.3-27.0)$ & 0.361 \\
\hline Height, percentile & 45 & $72.6(<1->99)$ & 13 & $50.1(<1-92.5)$ & 7 & $72.7(9.8-96.4)$ & 25 & $80.0(<1->99)$ & 0.350 \\
\hline Weight, percentile & 45 & $19.3(<1-98.3)$ & 13 & $19.2(<1-98.3)$ & 7 & $6.0(<1-92.9)$ & 25 & $22.9(<1-89)$ & 0.820 \\
\hline Creatinuria, mg/kg/24 h & 21 & $3.1(0.1-22.3)$ & 6 & $10.6(5-22.3)$ & 2 & $6.9(3.5-10.4)$ & 13 & $1.7(0.1-3.9)$ & $0.001^{\mathrm{b}}$ \\
\hline Diastolic BP, mm Hg & 43 & $61(10-104)$ & 13 & $59(10-79)$ & 6 & $62(52-80)$ & 24 & $65(46-104)$ & 0.428 \\
\hline Systolic BP, mm Hg & 43 & $103(81-147)$ & 13 & $110(84-147)$ & 6 & $103.5(88-123)$ & 24 & $102.5(81-142)$ & 0.691 \\
\hline Heart rate, bpm & 43 & $107(58-155)$ & 12 & $111.5(58-138)$ & 6 & $107.5(66-148)$ & 25 & $105(70-155)$ & 0.978 \\
\hline Respiratory rate, bpm & 39 & $25(14-70)$ & 11 & $22(14-37)$ & 5 & $24(15-70)$ & 23 & $27(14-48)$ & 0.502 \\
\hline Hours on ventilation & $31 / 31$ & $24(8-24)$ & - & - & 7 & $10(8-10)$ & 24 & $24(12-24)$ & - \\
\hline No. of respiratory infections/y & $32 / 32$ & $1(1-6)$ & 9 & $2(1-6)$ & 5 & $2(1-5)$ & 18 & $1(1-4)$ & 0.106 \\
\hline FVC, \% & $12 / 15$ & $33.35(6.3-61.9)$ & $8 / 9$ & $44.4(30.4-61.9)$ & $3 / 3$ & $25.3(18.4-26.5)$ & $1 / 3$ & 6.3 & $0.022^{\mathrm{b}}$ \\
\hline $\mathrm{FEV}_{1}, \%$ & $12 / 15$ & $37.7(6.8-62.3)$ & $8 / 9$ & $40.3(27.6-62.3)$ & $3 / 3$ & $18.9(16-28.1)$ & $1 / 3$ & 6.8 & $0.033^{b}$ \\
\hline MEP, \% & $13 / 15$ & $25.1(11.7-76.7)$ & $8 / 9$ & $30.8(18.3-76.7)$ & $3 / 3$ & $23.0(13.5-54.6)$ & $2 / 3$ & $12.3(11.7-13.0)$ & 0.065 \\
\hline MIP, \% & $13 / 15$ & $34.0(4.9-83.9)$ & $8 / 9$ & $42.8(0.2-83.9)$ & $3 / 3$ & $22.3(21.9-45.7)$ & $2 / 3$ & $11.7(4.9-18.5)$ & 0.055 \\
\hline PCF, \% & $12 / 15$ & $35.6(21.8-61.3)$ & $8 / 9$ & $45.1(30.7-61.3)$ & $3 / 3$ & $26.0(23.0-26.1)$ & $1 / 3$ & 21.8 & $0.022^{b}$ \\
\hline Grip strength, \% & $19 / 24$ & $21.7(0.4-97.7)$ & $9 / 9$ & $24.4(4.8-97.7)$ & $3 / 3$ & $53.1(17.1-61.7)$ & $7 / 12$ & $4.6(0.4-25.4)$ & $0.016^{\mathrm{b}}$ \\
\hline Pinch strength, \% & $21 / 24$ & $25.6(0.6-105.7)$ & $9 / 9$ & $45.2(8.7-105.7)$ & $3 / 3$ & $74.4(34.7-84.0)$ & $9 / 12$ & $7.1(0.6-47.3)$ & $0.010^{b}$ \\
\hline MFM20 total, \% & $9 / 9$ & $28.3(16.7-66.7)$ & $2 / 2$ & $65.8(65.0-66.7)$ & $2 / 2$ & $29.2(26.7-31.7)$ & $5 / 5$ & $25.0(16.7-33.3)$ & 0.102 \\
\hline MFM32 total, \% & $22 / 24$ & $31.3(0-93.8)$ & $9 / 9$ & $69.8(47.9-93.8)$ & $2 / 3$ & $39.1(22.9-55.2)$ & $11 / 12$ & $15.5(0-31.25)$ & $0.000^{\mathrm{b}}$ \\
\hline MoviPlate, $n$ & $19 / 24$ & $51(11-108)$ & $9 / 9$ & $66(31-108)$ & $3 / 3$ & $68(65-71)$ & $7 / 12$ & $33(11-64)$ & $0.030^{\mathrm{b}}$ \\
\hline CHOP-INTEND, $n$ & $12 / 12$ & $35.5(20-47)$ & $2 / 2$ & $41(40-42)$ & $2 / 2$ & $37(33-41)$ & $8 / 8$ & $27.5(20-47)$ & 0.452 \\
\hline MHFMS, $\mathbf{n}$ & $21 / 21$ & $2(0-32)$ & $4 / 4$ & $13.5(2-32)$ & $4 / 4$ & $2(0-5)$ & $13 / 13$ & $1(0-6)$ & $0.027^{b}$ \\
\hline NSAA, $n$ & $8 / 9$ & $18(6-32)$ & $8 / 8$ & $18(6-32)$ & $0 / 1$ & - & - & - & - \\
\hline \multirow[t]{2}{*}{ 6MWD, m } & $9 / 9$ & $302(185-644)$ & $8 / 8$ & $351.5(185-644)$ & $1 / 1$ & 235 & - & - & - \\
\hline & & & & & & & & & Continued \\
\hline
\end{tabular}


higher in more severely affected patients but the difference did not reach statistical significance (median durations of 89, 120, and 154 days in mild, intermediate, and severe phenotypes, respectively). During the 1-year follow-up, 37 patients reported between 1 and 11 adverse events, and 37 patients reported using concomitant treatment (median number of 5).

Patient Reported Outcomes Measurement Information System $\mathrm{T}$ scores for emotional distress, fatigue and pain interference averaged $80 \%$ of that of the general population. It was surprising that mild adult patients appeared more affected than other groups. Except for 2 ambulant children, patients reported a severe impairment in physical function, although social functions were within normal limits or mildly or moderately affected (data available from Dryad, figure e-1, doi.org/10.5061/dryad.c392v5q). Patients reported a median number of 2 social events missed because of the disease with some severe patients reporting up to 30 .

\section{Clinical changes over 1 year}

We focused on changes in upper limb strength and motor and pulmonary function using standardized assessments. Forty patients completed their 12-month visit. Three of the 12 patients enrolled before the age of 2 years died during the first year of the study due to cardiorespiratory arrest for 2 severe patients and probable sepsis for the third intermediate patient. Despite variability between patients, pulmonary function scores were stable over the 1-year period with standardized response means lower than 0.3 (figure 2 and table 3 ). The most reproducible tests were the FVC and MEP.

Grip and pinch strengths were numerically decreased over the year in the intermediate and severe groups, but changes did not reach statistical significance (figure $3 \mathrm{~A}$ and table 3 ). Functional scales MFM20 and MHFMS were stable in the infant group. MFM32 significantly decreased by 2.3 points over 1 year (figure $3 \mathrm{~B}$ and table 3 ). Timed tests performed in ambulant patients were stable over 1 year but we observed a large variability between patients in the 6-minute walk distance (table 3).

No changes were observed in physical examination and ophthalmoparesis. The degree of respiratory support did not change appreciably over 1 year except in 2 patients: one from the mild group who required nighttime respiratory support 12 months after enrollment, and the other from the severe group who changed ventilation from invasive to noninvasive. Similarly, the feeding status was stable over 1 year, and no specific changes in liver abnormalities were noted except in 2 children with a mild phenotype who changed from upper limit normal to hepatomegaly status. Lastly, there was no indication that patients treated with pyridostigmine had different outcomes.

\section{Seroprevalence of anti-AAV8 neutralizing antibodies}

Anti-AAV8 neutralizing activity $(\geq 1: 1)$ was detected in 10 of 38 available XLMTM serum samples, which represents 


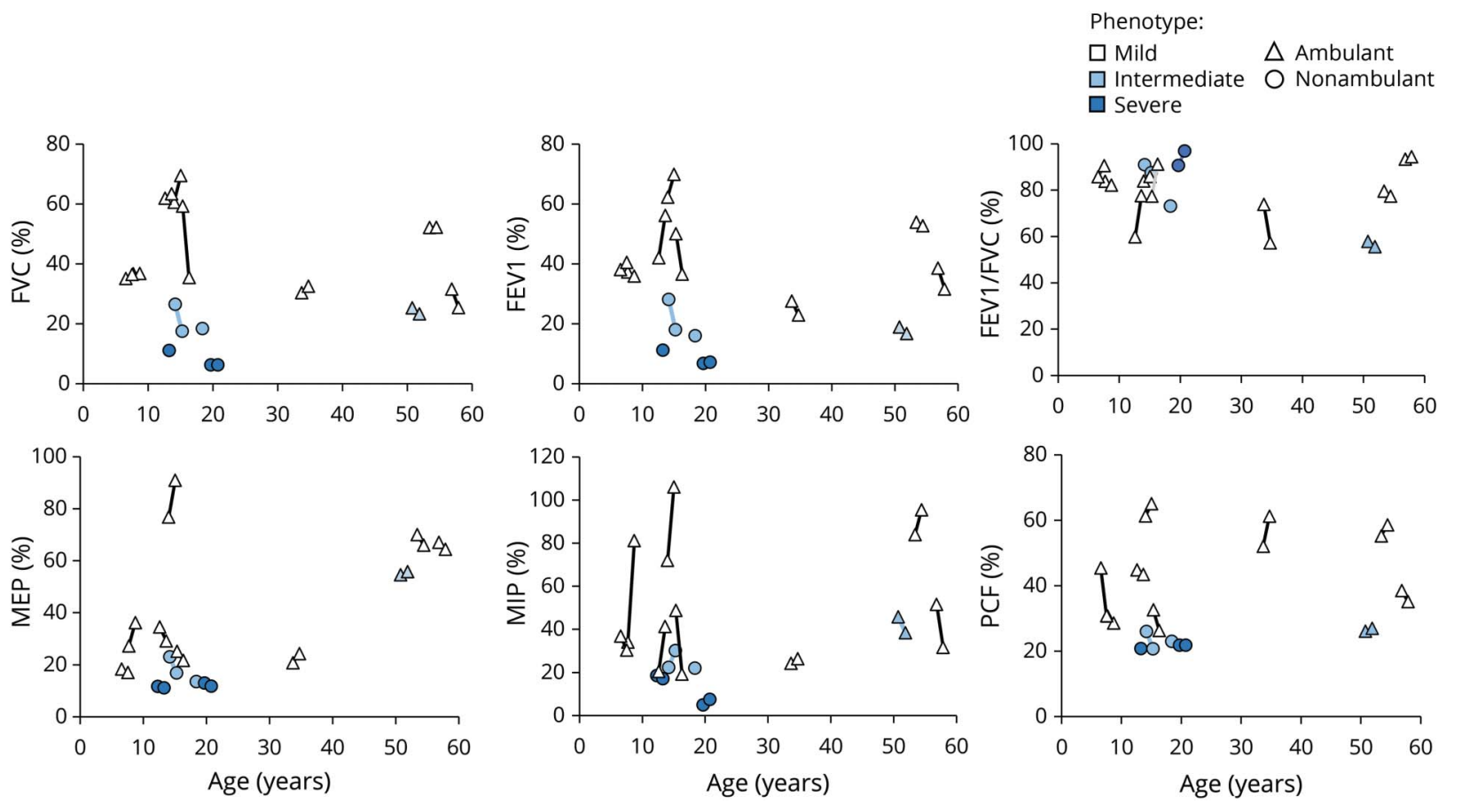

Pulmonary function in percentage of predicted value for age at baseline and 12-month visit. FEV ${ }_{1}=$ forced expiratory volume in the first second of exhalation; FVC = forced vital capacity; MEP = maximum expiratory pressure; MIP = maximum inspiratory pressure; PCF = peak cough flow.

a prevalence of $26.3 \%$ (table 1 ). Among those 10 samples, 2 were associated with an inhibitory titer greater than 1:10; these samples were from 1.7- and 50.8-year-old patients. Total immunoglobulin G levels specific for AAV8 were not quantified.

\section{Discussion}

We report 1-year follow-up data regarding male patients with XLMTM aged from 3.5 months to 56.8 years evaluated by standardized assessments adjusted according to age and ambulatory and respiratory status. Of note, the MFM32 revealed a significant drop over 1 year, making it an attractive outcome measure for future clinical trials. Many additional outcomes (e.g., pulmonary function tests or grip and pinch strength) remained stable over the 1-year observation period.

Knowledge of the natural history of a disease is essential to build an effective clinical development program, especially when developing drugs to treat rare diseases like XLMTM. The Food and Drug Administration, in the 21st Century Cures Act, noted the importance of natural history in understanding the full spectrum of a disease, including the need for a description of genotypic and phenotypic manifestations and distinct subpopulations affected. In addition, natural history studies improve understanding of how the condition progresses and how it can be most effectively treated. In the
Duchenne field, the understanding of outcome measures and natural history available after the first large international pivotal trials underlined how clinical development is affected by the absence of good knowledge of the natural history. Indeed, drisapersen demonstrated clinical efficacy in a phase 2 trial conducted in younger and stronger patients, ${ }^{34}$ but in phase 3 , testing did not show efficacy in a more rapidly declining population. ${ }^{35}$ In contrast, study of the natural history of patients with spinal muscular atrophy type $1^{36}$ allowed a better appreciation of progress in an open label trial ${ }^{37}$ and paved the way for a successful phase 3 trial. Gaining solid natural history data through a study that meets industry and regulatory standards is a strategy that was successfully used in patients with spinal muscular atrophy types 2 and $3,{ }^{38}$ Pompe disease $^{39}$ and hypophosphatasia. ${ }^{40}$

Our international natural history study in patients with XLMTM was designed to collect data using standardized procedures with quality matching interventional studies. We chose standardized assessments regularly used in clinical trials for neuromuscular disorders such as Duchenne muscular dystrophy and spinal muscular atrophy since no outcome measure is currently validated in XLMTM. We limited the number of evaluators by recruiting a dedicated physiotherapist who assessed half of the enrolled patients and carefully trained the other participating physiotherapists to ensure uniformity. In addition, all data were quality controlled by regular site visits. 


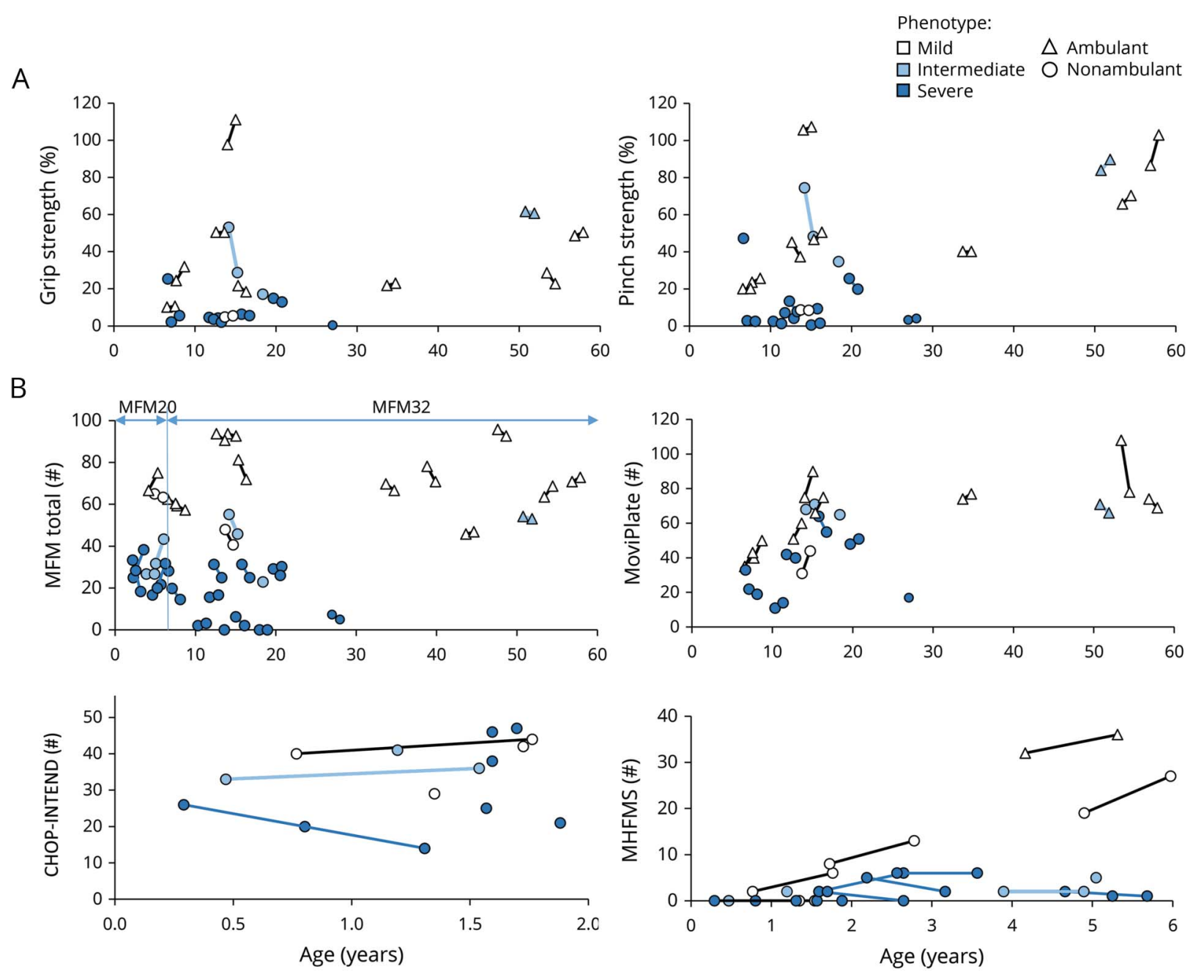

(A) Upper limb muscle strength and (B) motor function at baseline and 12-month visit. CHOP-INTEND = Children's Hospital of Philadelphia Infant Test of Neuromuscular Disorders; MFM = Motor Function Measure; MHFMS = Modified Hammersmith Functional Motor Scale.

Clinical characteristics of the population described here are consistent with previous cohorts described. ${ }^{710-12,41,42} \mathrm{Hy}-$ potonia and respiratory distress at birth were common, leading to long hospital stays during the first years of life. A quarter of patients enrolled before 2 years of age did not survive the first year of the study, which is consistent with data found in one study ${ }^{10}$ but less than half the number reported in other retrospective studies. ${ }^{7,11,41}$ This difference may be explained by the fact that we enrolled living patients and may also reflect improvements in standard of care and more aggressive treatment in the neonatal period. As expected, long-term survivors were often nonambulant and ventilator-dependent and feeding tube-dependent. Nevertheless, ambulation was conserved in $29 \%$ of patients enrolled at over 2 years of age. Motor milestone acquisitions were generally delayed regardless of phenotype. Comorbidities were similar to those previously described ${ }^{7,10,12,42}$ with a predominance of genitourinary disorders, facial muscle weakness, frequent lower respiratory tract infections, and scoliosis, all of which were more prevalent in the most severe patients.

One of the main findings of this study is that XLMTM is clearly progressive. Contrary to observations made by others, ${ }^{12}$ our data establish that substantial motor milestones previously acquired were lost by several patients including those mildly affected. In addition, motor function assessed consistently by the general function scale MFM32 decreased significantly over 1 year in long-term survivors older than 6 years. It must be noted that a 2-point decrease in MFM may not be clinically relevant. Over a longer term, however, the retrospective assessment of motor development clearly demonstrates that major function may be lost during the life of a patient with XLMTM, even if years of observation are needed before changes are clinical meaningful. Standardized pulmonary function test, motor function test other than MFM32, and upper limb strength test scores remained stable over 1 year, confirming the very slow progression of the disease. 


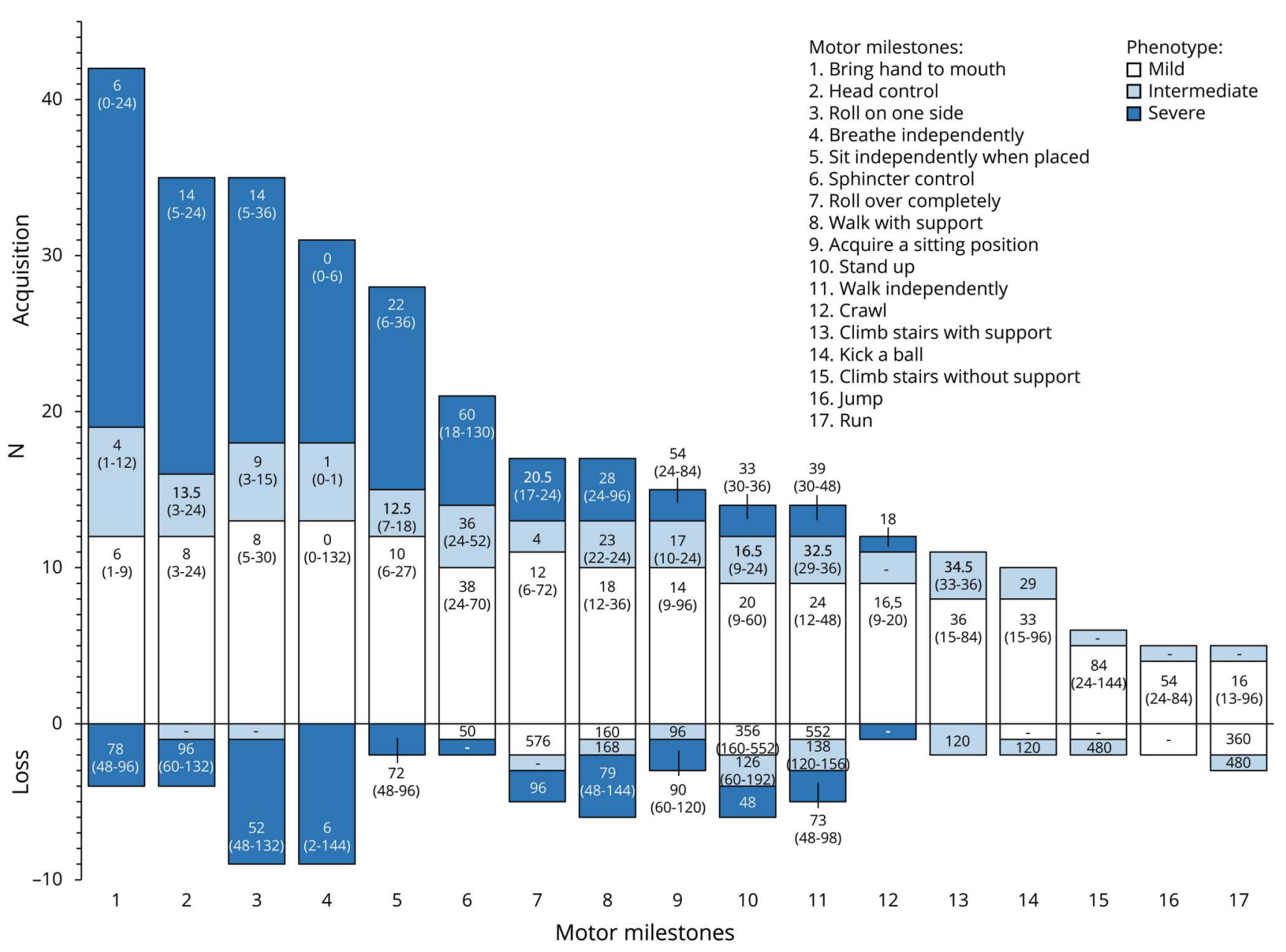

Median ages of acquisition and loss of motor milestones. Ages are expressed in months.

The fact that some patients lost previously acquired motor milestones suggests that XLMTM disease progression presents as do many neuromuscular diseases, such as $\mathrm{Du}$ chenne muscular dystrophy and spinal muscular atrophy type 3, with an initial period of positive evolution followed by a progressive loss of muscle strength and motor function. The maximal ability achieved and the timing of decline differs among patients, ranging from nearly no motor acquisition to full motor development. The major determinant of this evolution is certainly the genotype. Genotype-phenotype correlation is consistent with the previous observation that some mutations are expected to be associated with a mild or intermediate phenotype, probably because of a residual function of the mutated myotubularin, whereas complete loss of function is linked to the most severe phenotype. ${ }^{43}$ In addition, a mutated amino acid may be a predictor of severity when located in a functional domain of the protein. Indeed, missense mutations that alter the phosphatase consensus active site (PTP) in exon 11 or mutations located in the nearby SET interaction domain (SID domain) in exons 12 and 13 are mainly associated with the severe phenotype. ${ }^{44}$ In our study, duplications and nonsense mutations in exons 12 and 13 were indeed associated with a severe phenotype, but 2 missense mutations and one nonsense mutation in exon 11 were associated with a mild phenotype. Mutations could induce an abnormal protein structure that is not obviously predicted. Point mutations may act as missense mutations or may affect splice sites or exonic splicing enhancers or silencers that are important for splicing modulation. Indeed, the mutation c.205C $>\mathrm{T}$, which is predicted to lead to the missense p.Arg69Cys, may also alter splicing patterns and lead to variation in the amount of residual function of the mutated protein among patients, explaining the associations with mild and severe phenotypes. ${ }^{45}$

Despite the population heterogeneity, our study provides some data on potential outcome measures applicable for analyzing the effects of future therapeutics. The MFM32 scale was sensitive to change over 1 year, and thus may constitute a suitable outcome for therapeutics that aim to stabilize patients. The MFM32 scale was particularly 
Table 3 Changes over 1 year

\begin{tabular}{|c|c|c|c|c|c|c|c|c|c|c|c|c|}
\hline \multirow[b]{2}{*}{ Median changes over $1 \mathrm{y}^{\mathrm{a}}$} & \multicolumn{3}{|l|}{ All } & \multicolumn{3}{|l|}{ Mild } & \multicolumn{3}{|c|}{ Intermediate } & \multicolumn{3}{|c|}{ Severe } \\
\hline & No. & Median ( $\min$ to $\max$ ) & SRM & No. & Median ( $\min$ to $\max$ ) & SRM & No. & Median (min to max) & SRM & No. & Median (min to max) & SRM \\
\hline FVC, \% & 11 & 0.1 (-23.9 to 8.9$)$ & 0.29 & 8 & $0.8(-23.9$ to 8.9$)$ & 0.21 & 2 & $-5.5(-9.0$ to -2.0$)$ & - & 1 & 6.3 & - \\
\hline $\mathrm{FEV}_{1}, \%$ & 11 & $-1.4(-13.5$ to 14.2$)$ & 0.18 & 8 & $-1.3(-13.5$ to 14.2$)$ & 0.05 & 2 & $-6.2(-10.1$ to -2.2$)$ & - & 1 & 0.4 & - \\
\hline MEP, \% & 12 & $-1.2(-6.2$ to 14.2$)$ & 0.04 & 8 & $-2.0(-5.4$ to 14.2$)$ & 0.07 & 2 & $-2.5(-6.2$ to 1.2$)$ & - & 2 & $-0.9(-1.2$ to -0.6$)$ & - \\
\hline MIP, \% & 12 & $2.3(-29.6$ to 47.1$)$ & 0.24 & 8 & $6.8(-29.6$ to 47.1$)$ & 0.28 & 2 & $0.3(-7.3$ to 7.9$)$ & - & 2 & $0.5(-1.5$ to 2.5$)$ & - \\
\hline PCF, \% & 11 & $-1.4(-14.6$ to 9.2$)$ & 0.23 & 8 & -1.8 (-14.6 to 9.2$)$ & 0.20 & 2 & $-2.2(-5.3$ to 0.9$)$ & - & 1 & 0.0 & - \\
\hline Grip strength, \% & 17 & $0.0(-24.4$ to 13.5$)$ & 0.09 & 9 & $0.6(-5.8$ to 13.5$)$ & 0.31 & 2 & $-12.7(-24.4$ to -1.0$)$ & - & 6 & $-0.6(-1.9$ to 3.4$)$ & 0.12 \\
\hline Pinch strength, \% & 19 & $0.0(-26.2$ to 16.3$)$ & 0.15 & 9 & $1.6(-7.8$ to 16.3$)$ & 0.35 & 2 & $-10.2(-26.2$ to 5.8$)$ & - & 8 & $-2.1(-9.4$ to 1.0$)$ & 0.78 \\
\hline MFM20 total, $n$ & 8 & $6.7(-15$ to 11.7$)$ & 0.41 & 2 & $3.3(-1.7$ to 8.3$)$ & - & 2 & $5.8(0$ to 11.7$)$ & - & 4 & $7.5(-15$ to 11.7$)$ & 0.24 \\
\hline MFM32 total, $n$ & 19 & $-2.3^{\mathrm{b}}(-9.4$ to 5.2$)$ & 0.68 & 9 & $-2.1(-9.4$ to 5.2$)$ & 0.53 & 1 & -5.2 & - & 9 & $-2.3(-6.3$ to 1.0$)$ & 0.73 \\
\hline MoviPlate, $n$ & 16 & $3(-30$ to 15$)$ & 0.13 & 9 & $9(-30$ to 15$)$ & 0.26 & 2 & $-1(-5$ to 3$)$ & - & 5 & $-2(-9$ to 3$)$ & 0.32 \\
\hline CHOP-INTEND, $n$ & 3 & $3.0(-12$ to 4$)$ & 0.19 & 1 & 4.0 & - & 1 & 3.0 & - & 1 & -12.0 & - \\
\hline MHFMS, $n$ & 13 & $0.0(-3$ to 6$)$ & 0.46 & 4 & 4.5 (4 to 8 ) & 2.77 & 2 & 0.0 (0 to 0$)$ & - & 7 & 0.0 (-3 to 4$)$ & 0.13 \\
\hline NSAA, $n$ & 9 & $1(-4$ to 7$)$ & 0.27 & 8 & $1(-4$ to 7$)$ & 0.38 & 1 & -2 & - & - & - & - \\
\hline 6MWD, m & 8 & $9(-122$ to 56.5$)$ & 0.01 & 7 & $25(-122$ to 56.5$)$ & 0.01 & 1 & -7 & - & - & - & - \\
\hline Time to run/walk $10 \mathrm{~m}, \mathrm{~s}$ & 7 & 0 (-0.9 to 0.3$)$ & 0.38 & 7 & 0 (-0.9 to 0.3$)$ & 0.36 & - & - & - & - & - & - \\
\hline Time to rise from floor, $\mathrm{s}$ & 2 & 0.7 (0.1 to 1.3$)$ & - & 2 & 0.7 (0.1 to 1.3$)$ & - & - & - & - & - & - & - \\
\hline
\end{tabular}

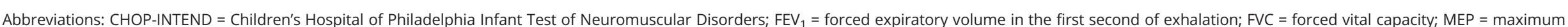

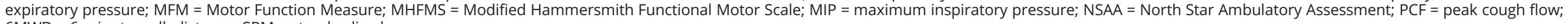
$6 \mathrm{MWD}=6$-minute walk distance; SRM = standardized response mean. a Wilcoxon test. 
interesting for the adult population in whom growth is not a confounding factor.

Pulmonary function tests established that the pulmonary function of patients with XLMTM was abnormal even in ventilator independent patients, which is consistent with previously published data. ${ }^{46}$ The stability over 1 year and the universally decreased respiratory function among phenotypes make pulmonary function testing a suitable outcome for therapeutics aiming to improve patient respiratory status. The same applies for MyoGrip and MyoPinch, which could be used in most patients and for which no ceiling effect was observed.

Since gene therapy using an AAV8 is under development for myotubular myopathy ${ }^{15,47}$ and currently tested in a clinical trial (NCT03199469), we monitored the levels of neutralizing antibodies against AAV8 in patients as humoral immunity may jeopardize efficient gene transfer. We found that about $25 \%$ of patients had detectable levels of neutralizing antibodies and only 2 patients had high inhibitory levels, meaning that at least $5 \%$ of patients (for a threshold titer of $1: 10$ ) would not be treatable by an AAV8-based gene therapy. These seroprevalence values were lower than those observed in patients affected by Duchenne muscular dystrophy, ${ }^{48}$ probably because of the lower mean age of patients in our cohort.

Our study has some limitations. First, patients were highly heterogeneous leading to the need to stratify the population for analyses resulting in small and unbalanced sample sizes and therefore the necessity of using nonparametric statistical analyses that are highly conservative. This limitation is intrinsic to this disease and prospectively following a much larger cohort would be very difficult since this cohort was gathered through a large international effort. Second, we observed high variability between and within patients over 1 year, potentially masking a general trend. This may reflect the variability of the disease evolution between patients as some patients are in their decline phase, whereas others are still progressing. Alternatively, it may reflect the poor reliability of measures performed in very weak patients or a learning effect. In the protocol, we balanced test and retest assessments against fatigue, which is a well-known symptom in patients with XLMTM who present with neuromuscular junction symptoms. ${ }^{49,50}$ Follow-up for a longer time period will help address this issue. Another limitation is that pulmonary function was not assessed in patients with tracheostomy. Consequently, it was assessed in only a few severe patients, thus reducing the sample size for accurate comparison. Lastly, the cohort was skewed toward moderate and mild patients, but most studies suggest that $80 \%$ of all patients with XLMTM have the severe form. This is probably attributable to the design of the study. Indeed, the study aimed to include all living patients with a genetically confirmed diagnosis of XLMTM. Since diagnosis of XLMTM is frequently delayed, many patients are beyond the neonatal period when confirmatory genetic testing is performed and some severe patients died before receiving a molecular diagnosis. In addition, we did not declare neonatal intensive care units as investigational sites and patients requiring intensive care were likely not seen in declared neuromuscular centers and enrolled in the natural history study unless the intensive care unit was located in the same hospital. This study should thus be considered as a natural history study of patients surviving beyond the neonatal period, since very few patients in the neonatal intensive care unit were included. In this view, this analysis is complementary to the Inceptus study (NCT02704273) that covers younger patients with respiratory involvement. Our analysis demonstrated the slow progressive nature of the disease and identified disease burden and outcome measures suitable for clinical trials in male patients with XLMTM who survive the neonatal period.

\section{Acknowledgment}

The authors are very grateful to the patients for their participation in this prospective natural history study and to the staff of all sites who assessed these patients and kindly welcomed patients from many locales to the study. The authors thank Jackie Wyatt for editing. They also thank S. Triffault from GenoSafe and P. Veron for advice on the immunological study; K. Amburgey, B. Andres, E. Bertini, R. Cardas, S. Denis, D. Duchêne, V. Latournerie, N. Reguiba, A.M. Seferian, E. Tsuchiya, and C. Wallgren-Pettersson for their roles in data acquisition and quality control; and G. Honnet, J. Laporte, and D. Ramsdell for their advice on the study.

\section{Study funding}

Valerion Therapeutics, LLC (Concord, MA) and Genethon cofunded the first 3 years of the NatHis-MTM study.

\section{Disclosure}

M. Annoussamy, C. Lilien, T. Gidaro, E. Gargaun, V. Chê, U. Schara, A. Gangfuß, and A. D'Amico report no disclosures relevant to the manuscript. J. Dowling receives consultant fees from Dynacure, a company developing treatment for patients with XLMTM, and is a member of the scientific advisory board of the RYR1 Foundation. B. Darras, A. Daron, A. Hernandez, C. de Lattre, J. Arnal, M. Mayer, J. Cuisset, C. Vuillerot, S. Fontaine, R. Bellance, and V. Biancalana report no disclosures relevant to the manuscript. A. Buj-Bello is an inventor of a patent on MTM1 gene therapy for XLMTM. J. Hogrel is coinventor of MyoGrip, MyoPinch, and MoviPlate devices. H. Landy is Chief Medical Officer of Valerion Therapeutics and a shareholder. L. Servais is coinventor of MoviPlate device and receives consultant fees from Dynacure, which is developing treatment for patients with XLMTM. Go to Neurology.org/ $\mathrm{N}$ for full disclosures.

\section{Publication history}

Received by Neurology September 19, 2018. Accepted in final form December 20, 2018. 
Appendix Authors

\begin{tabular}{|c|c|c|c|}
\hline Name & Location & Role & Contribution \\
\hline $\begin{array}{l}\text { Mélanie } \\
\text { Annoussamy, } \\
\text { PhD }\end{array}$ & $\begin{array}{l}\text { I-Motion, Institute } \\
\text { of Myology, Paris, } \\
\text { France }\end{array}$ & Author & $\begin{array}{l}\text { Designed and } \\
\text { conceptualized the } \\
\text { study, analyzed } \\
\text { and interpreted the } \\
\text { data, drafted the } \\
\text { manuscript for } \\
\text { intellectual conten }\end{array}$ \\
\hline $\begin{array}{l}\text { Charlotte } \\
\text { Lilien, } \\
\text { Physiotherapist }\end{array}$ & $\begin{array}{l}\text { I-Motion, Institute } \\
\text { of Myology, Paris, } \\
\text { France }\end{array}$ & Author & $\begin{array}{l}\text { Major roles in the } \\
\text { acquisition of data, } \\
\text { training of } \\
\text { physiotherapists, } \\
\text { and manuscript } \\
\text { revision }\end{array}$ \\
\hline $\begin{array}{l}\text { Teresa Gidaro, } \\
\text { MD, PhD }\end{array}$ & $\begin{array}{l}\text { I-Motion, Institute } \\
\text { of Myology, Paris, } \\
\text { France }\end{array}$ & Author & $\begin{array}{l}\text { Major roles in the } \\
\text { acquisition of data } \\
\text { and manuscript } \\
\text { revision }\end{array}$ \\
\hline $\begin{array}{l}\text { Elena Gargaun, } \\
\text { MD }\end{array}$ & $\begin{array}{l}\text { I-Motion, Institute } \\
\text { of Myology, Paris, } \\
\text { France }\end{array}$ & Author & $\begin{array}{l}\text { Major roles in the } \\
\text { acquisition of data } \\
\text { and manuscript } \\
\text { revision }\end{array}$ \\
\hline Virginie Chê & $\begin{array}{l}\text { I-Motion, Institute } \\
\text { of Myology, Paris, } \\
\text { France }\end{array}$ & Author & $\begin{array}{l}\text { Major roles in the } \\
\text { acquisition of data, } \\
\text { study control } \\
\text { quality, and } \\
\text { manuscript revision }\end{array}$ \\
\hline $\begin{array}{l}\text { Ulrike Schara, } \\
\text { MD }\end{array}$ & $\begin{array}{l}\text { Paediatric } \\
\text { Neurology and } \\
\text { Neuromuscular } \\
\text { Center, University } \\
\text { of Essen, Germany }\end{array}$ & Author & $\begin{array}{l}\text { Major roles in the } \\
\text { acquisition of data } \\
\text { and manuscript } \\
\text { revision }\end{array}$ \\
\hline $\begin{array}{l}\text { Andrea } \\
\text { Gangfuß, MD }\end{array}$ & $\begin{array}{l}\text { Paediatric } \\
\text { Neurology and } \\
\text { Neuromuscular } \\
\text { Center, University } \\
\text { of Essen, Germany }\end{array}$ & Author & $\begin{array}{l}\text { Major roles in the } \\
\text { acquisition of data, } \\
\text { and manuscript } \\
\text { revision }\end{array}$ \\
\hline $\begin{array}{l}\text { Adele D'Amico, } \\
\text { MD }\end{array}$ & $\begin{array}{l}\text { Unit of } \\
\text { Neuromuscular and } \\
\text { Neurodegenerative } \\
\text { Disorders, } \\
\text { Department of } \\
\text { Neurosciences, } \\
\text { Bambino Gesu } \\
\text { Children's Research } \\
\text { Hospital IRCCS, } \\
\text { Rome, Italy }\end{array}$ & Author & $\begin{array}{l}\text { Major roles in the } \\
\text { acquisition of data } \\
\text { and manuscript } \\
\text { revision }\end{array}$ \\
\hline
\end{tabular}

\begin{tabular}{|c|c|c|c|}
\hline $\begin{array}{l}\text { James J. } \\
\text { Dowling, MD }\end{array}$ & $\begin{array}{l}\text { Hospital for Sick } \\
\text { Children, Toronto, } \\
\text { Canada }\end{array}$ & Author & $\begin{array}{l}\text { Major role in the } \\
\text { acquisition of data } \\
\text { and reviewed the } \\
\text { manuscript for } \\
\text { intellectual content }\end{array}$ \\
\hline $\begin{array}{l}\text { Basil T. Darras, } \\
\text { MD }\end{array}$ & $\begin{array}{l}\text { Boston Children's } \\
\text { Hospital, MA }\end{array}$ & Author & $\begin{array}{l}\text { Major role in the } \\
\text { acquisition of data } \\
\text { and reviewed the } \\
\text { manuscript for } \\
\text { intellectual content }\end{array}$ \\
\hline $\begin{array}{l}\text { Aurore Daron, } \\
\text { MD }\end{array}$ & $\begin{array}{l}\text { Centre de } \\
\text { Référence } \\
\text { Neuromusculaire, } \\
\text { CHR La Citadelle, } \\
\text { Liège, Belgium }\end{array}$ & Author & $\begin{array}{l}\text { Major roles in the } \\
\text { acquisition of data } \\
\text { and manuscript } \\
\text { revision }\end{array}$ \\
\hline $\begin{array}{l}\text { Arturo } \\
\text { Hernandez, MD, } \\
\text { PhD }\end{array}$ & $\begin{array}{l}\text { UCI Pediatrica, } \\
\text { Hospital Puerta del } \\
\text { Mar, Cadiz, Spain }\end{array}$ & Author & $\begin{array}{l}\text { Major roles in the } \\
\text { acquisition of data } \\
\text { and manuscript } \\
\text { revision }\end{array}$ \\
\hline
\end{tabular}

Appendix (continued)

\begin{tabular}{|c|c|c|c|}
\hline Name & Location & Role & Contribution \\
\hline $\begin{array}{l}\text { Capucine de } \\
\text { Lattre, MD }\end{array}$ & $\begin{array}{l}\text { Centre de } \\
\text { Référence Maladies } \\
\text { Neuromusculaires } \\
\text { Adulte, Hôpital de la } \\
\text { Croix-Rousse, } \\
\text { Hospices Civils de } \\
\text { Lyon, France }\end{array}$ & Author & $\begin{array}{l}\text { Major roles in the } \\
\text { acquisition of data } \\
\text { and manuscript } \\
\text { revision }\end{array}$ \\
\hline $\begin{array}{l}\text { Jean-Michel } \\
\text { Arnal, MD }\end{array}$ & $\begin{array}{l}\text { Service de } \\
\text { Réanimation } \\
\text { Polyvalente, Hôpital } \\
\text { Sainte Musse, } \\
\text { Toulon, France }\end{array}$ & Author & $\begin{array}{l}\text { Major roles in the } \\
\text { acquisition of data } \\
\text { and manuscript } \\
\text { revision }\end{array}$ \\
\hline $\begin{array}{l}\text { Michèle Mayer, } \\
\text { MD }\end{array}$ & $\begin{array}{l}\text { Centre de Référence } \\
\text { des Maladies } \\
\text { Neuromusculaires } \\
\text { d'lle de } \\
\text { France-Nord et EST, } \\
\text { Hôpital Armand } \\
\text { Trousseau, Paris, } \\
\text { France }\end{array}$ & Author & $\begin{array}{l}\text { Major roles in the } \\
\text { acquisition of data } \\
\text { and manuscript } \\
\text { revision }\end{array}$ \\
\hline $\begin{array}{l}\text { Jean-Marie } \\
\text { Cuisset, MD }\end{array}$ & $\begin{array}{l}\text { Service de } \\
\text { Neuropédiatrie } \\
\text { Hôpital Roger } \\
\text { Salengro, CHRU, } \\
\text { Lille, France }\end{array}$ & Author & $\begin{array}{l}\text { Major roles in the } \\
\text { acquisition of data } \\
\text { and manuscript } \\
\text { revision }\end{array}$ \\
\hline $\begin{array}{l}\text { Carole } \\
\text { Vuillerot, MD }\end{array}$ & $\begin{array}{l}\text { Service de } \\
\text { Rééducation } \\
\text { Pédiatrique } \\
\text { "L'Escale," Hôpital } \\
\text { Mère Enfant, CHU- } \\
\text { Lyon, France }\end{array}$ & Author & $\begin{array}{l}\text { Major roles in the } \\
\text { acquisition of data } \\
\text { and manuscript } \\
\text { revision }\end{array}$ \\
\hline $\begin{array}{l}\text { Stéphanie } \\
\text { Fontaine, MD }\end{array}$ & $\begin{array}{l}\text { Service de } \\
\text { Rééducation } \\
\text { Pédiatrique } \\
\text { "L'Escale," Hôpital } \\
\text { Mère Enfant, CHU- } \\
\text { Lyon, France }\end{array}$ & Author & $\begin{array}{l}\text { Major roles in the } \\
\text { acquisition of data } \\
\text { and manuscript } \\
\text { revision }\end{array}$ \\
\hline $\begin{array}{l}\text { Rémi Bellance, } \\
\text { MD }\end{array}$ & $\begin{array}{l}\text { CeRCa, Hôpital } \\
\text { Pierre-Zobda- } \\
\text { Quitman, CHU de } \\
\text { Martinique, Fort- } \\
\text { de-France, } \\
\text { Martinique }\end{array}$ & Author & $\begin{array}{l}\text { Major roles in the } \\
\text { acquisition of data } \\
\text { and manuscript } \\
\text { revision }\end{array}$ \\
\hline $\begin{array}{l}\text { Valérie } \\
\text { Biancalana, } \\
\text { PhD }\end{array}$ & $\begin{array}{l}\text { Laboratoire } \\
\text { Diagnostic } \\
\text { Génétique, Nouvel } \\
\text { Hôpital Civil, } \\
\text { Strasbourg, } \\
\text { France }\end{array}$ & Author & $\begin{array}{l}\text { Major roles in data } \\
\text { acquisition, analysis } \\
\text { of the data, and } \\
\text { manuscript drafting }\end{array}$ \\
\hline $\begin{array}{l}\text { Ana Buj-Bello, } \\
\text { MD, PhD }\end{array}$ & $\begin{array}{l}\text { Genethon, UMR } \\
\text { S951 Inserm, Univ } \\
\text { Evry, Université } \\
\text { Paris Saclay, Evry, } \\
\text { France }\end{array}$ & Author & $\begin{array}{l}\text { Major roles in data } \\
\text { acquisition, analysis } \\
\text { of the data, and } \\
\text { manuscript drafting }\end{array}$ \\
\hline $\begin{array}{l}\text { Jean-Yves } \\
\text { Hogrel, PhD }\end{array}$ & $\begin{array}{l}\text { Neuromuscular } \\
\text { Investigation } \\
\text { Center, Institute of } \\
\text { Myology, Paris, } \\
\text { France }\end{array}$ & Author & $\begin{array}{l}\text { Participated in } \\
\text { study design, } \\
\text { reviewed the } \\
\text { manuscript for } \\
\text { intellectual content }\end{array}$ \\
\hline Hal Landy, MD & $\begin{array}{l}\text { Valerion } \\
\text { Therapeutics, } \\
\text { Concord, MA }\end{array}$ & Author & $\begin{array}{l}\text { Designed and } \\
\text { conceptualized the } \\
\text { study, interpreted } \\
\text { the data, reviewed } \\
\text { the manuscript for } \\
\text { intellectual } \\
\text { content }\end{array}$ \\
\hline
\end{tabular}


Appendix (continued)

\begin{tabular}{|c|c|c|c|}
\hline Name & Location & Role & Contribution \\
\hline $\begin{array}{l}\text { Laurent } \\
\text { Servais, MD, } \\
\text { PhD }\end{array}$ & $\begin{array}{l}\text { I-Motion, Institute } \\
\text { of Myology, Paris, } \\
\text { France }\end{array}$ & Author & $\begin{array}{l}\text { Designed and } \\
\text { conceptualized the } \\
\text { study, interpreted } \\
\text { the data, reviewed } \\
\text { the manuscript for } \\
\text { intellectual content }\end{array}$ \\
\hline
\end{tabular}

\section{References}

1. Vandersmissen I, Biancalana V, Servais L, et al. An integrated modelling methodology for estimating the prevalence of centronuclear myopathy. Neuromuscul Disord 2018; 28:766-777.

2. Taylor GS, Maehama T, Dixon JE. Myotubularin, a protein tyrosine phosphatase mutated in myotubular myopathy, dephosphorylates the lipid second messenger, phosphatidylinositol 3-phosphate. Proc Natl Acad Sci USA 2000;97:8910-8915.

3. Hnia K, Vaccari I, Bolino A, Laporte J. Myotubularin phosphoinositide phosphatases: cellular functions and disease pathophysiology. Trends Mol Med 2012;18:317-327.

4. Amoasii L, Hnia K, Laporte J. Myotubularin phosphoinositide phosphatases in human diseases. Curr Top Microbiol Immunol 2012;362:209-233.

5. Thomas NS, Williams H, Cole G, et al. X linked neonatal centronuclear/myotubular myopathy: evidence for linkage to Xq28 DNA marker loci. J Med Genet 1990;27: 284-287.

6. Dowling JJ, Vreede AP, Low SE, Gibbs JY, Bonnemann CG, Feldman EL. Loss of myotubularin function results in T-tubule disorganization in zebrafish and human myotubular myopathy. PLoS Genet 2009;5:e1000372.

7. McEntagart M, Parsons G, Buj-Bello A, et al. Genotype-phenotype correlations in X-linked myotubular myopathy. Neuromuscul Disord 2002;12:939-946.

8. Biancalana V, Caron O, Gallati S, et al. Characterisation of mutations in 77 patients with $\mathrm{X}$-linked myotubular myopathy, including a family with a very mild phenotype. Hum Genet 2003;112:135-142.

9. Hoffjan S, Thiels C, Vorgerd M, Neuen-Jacob E, Epplen JT, Kress W. Extreme phenotypic variability in a German family with X-linked myotubular myopathy associated with E404K mutation in MTM1. Neuromuscul Disord 2006;16:749-753.

10. Amburgey K, Tsuchiya E, de Chastonay S, et al. A natural history study of X-linked myotubular myopathy. Neurology 2017;89:1355-1364.

11. Beggs AH, Byrne BJ, De Chastonay S, et al. A multicenter, retrospective medical record review of X-linked myotubular myopathy: the recensus study. Muscle Nerve 2018;57:550-560.

12. Herman GE, Finegold M, Zhao W, de Gouyon B, Metzenberg A. Medical complications in long-term survivors with X-linked myotubular myopathy. J Pediatr 1999; 134:206-214.

13. Guiraud-Chaumeil C, Laporte J, Mandel JL, Warter JM. Myotubular myopathy [in French]. Rev Neurol 2000;156:960-964.

14. Buj-Bello A, Fougerousse F, Schwab Y, et al. AAV-mediated intramuscular delivery of myotubularin corrects the myotubular myopathy phenotype in targeted murine muscle and suggests a function in plasma membrane homeostasis. Hum Mol Genet 2008; 17:2132-2143.

15. Childers MK, Joubert R, Poulard K, et al. Gene therapy prolongs survival and restores function in murine and canine models of myotubular myopathy. Sci Transl Med 2014; 6:220ra10.

16. Lawlor MW, Armstrong D, Viola MG, et al. Enzyme replacement therapy rescues weakness and improves muscle pathology in mice with X-linked myotubular myopathy. Hum Mol Genet 2013;22:1525-1538.

17. Cowling BS, Chevremont T, Prokic I, et al. Reducing dynamin 2 expression rescues X-linked centronuclear myopathy. J Clin Invest 2014;124:1350-1363.

18. Tasfaout H, Buono S, Guo S, et al. Antisense oligonucleotide-mediated Dnm2 knockdown prevents and reverts myotubular myopathy in mice. Nat Commun 2017; $8: 15661$

19. Sabha N, Volpatti JR, Gonorazky H, et al. PIK3C2B inhibition improves function and prolongs survival in myotubular myopathy animal models. J Clin Invest 2016;126: 3613-3625.

20. Manno CS, Pierce GF, Arruda VR, et al. Successful transduction of liver in hemophilia by AAV-factor IX and limitations imposed by the host immune response. Nat Med 2006;12:342-347.

21. Scallan CD, Jiang H, Liu T, et al. Human immunoglobulin inhibits liver transduction by AAV vectors at low AAV2 neutralizing titers in SCID mice. Blood 2006;107: 1810-1817.

22. Forbes GB, Bruining GJ. Urinary creatinine excretion and lean body mass. Am J Clin Nutr 1976;29:1359-1366.
23. Servais L, Deconinck N, Moraux A, et al. Innovative methods to assess upper limb strength and function in non-ambulant Duchenne patients. Neuromuscul Disord 2013;23:139-148.

24. Hankinson JL, Odencrantz JR, Fedan KB. Spirometric reference values from a sample of the general U.S. population. Am J Respir Crit Care Med 1999;159:179-187.

25. Wilson SH, Cooke NT, Edwards RH, Spiro SG. Predicted normal values for maximal respiratory pressures in Caucasian adults and children. Thorax 1984;39:535-538.

26. Bianchi C, Baiardi P. Cough peak flows: standard values for children and adolescents. Am J Phys Med Rehabil 2008;87:461-467.

27. Glanzman AM, Mazzone E, Main M, et al. The Children's Hospital of Philadelphia Infant Test of Neuromuscular Disorders (CHOP INTEND): test development and reliability. Neuromuscul Disord 2010;20:155-161.

28. Krosschell KJ, Maczulski JA, Crawford TO, Scott C, Swoboda KJ. A modified Hammersmith functional motor scale for use in multi-center research on spinal muscular atrophy. Neuromuscul Disord 2006;16:417-426.

29. Bérard C, Payan C, Hodgkinson I, Fermanian J; MFM Collaborative Study Group. A motor function measure for neuromuscular diseases: construction and validation study. Neuromuscul Disord 2005;15:463-470.

30. de Lattre C, Payan C, Vuillerot C, et al. Motor function measure: validation of a short form for young children with neuromuscular diseases. Arch Phys Med Rehabil 2013, 94:2218-2226.

31. Mazzone E, Martinelli D, Berardinelli A, et al. North Star Ambulatory Assessment, 6-minute walk test and timed items in ambulant boys with Duchenne muscular dystrophy. Neuromuscul Disord 2010;20:712-716.

32. Scott E, Eagle M, Mayhew A, et al. Development of a functional assessment scale for ambulatory boys with Duchenne muscular dystrophy. Physiother Res Int 2012;17: 101-109.

33. McDonald CM, Henricson EK, Han JJ, et al. The 6-minute walk test as a new outcome measure in Duchenne muscular dystrophy. Muscle Nerve 2010;41:500-510.

34. Voit T, Topaloglu H, Straub V, et al. Safety and efficacy of drisapersen for the treatment of Duchenne muscular dystrophy (DEMAND II): an exploratory, randomised, placebo-controlled phase 2 study. Lancet Neurol 2014;13:987-996.

35. Goemans NM, Tulinius M, van den Hauwe M, et a. Long-term efficacy, safety, and pharmacokinetics of drisapersen in Duchenne muscular dystrophy: results from an open-label extension study. PLoS One 2016;11:e0161955.

36. Finkel RS, McDermott MP, Kaufmann P, et al. Observational study of spinal muscular atrophy type I and implications for clinical trials. Neurology 2014;83:810-817.

37. Finkel RS, Chiriboga CA, Vajsar J, et al. Treatment of infantile-onset spinal muscular atrophy with nusinersen: a phase 2, open-label, dose-escalation study. Lancet 2016; 388:3017-3026.

38. Chabanon A, Seferian AM, Daron A, et al. Prospective and longitudinal natural history study of patients with type 2 and 3 spinal muscular atrophy: baseline data NatHisSMA study. PLoS One 2018;13:e0201004.

39. Kishnani PS, Hwu WL, Mandel H, Nicolino F, Corzo D A retrospective, multinational, multicenter study on the natural history of infantile-onset Pompe disease. J Pediatr 2006;148:671-676.

40. Whyte MP, Wenkert D, Zhang F. Hypophosphatasia: natural history study of 101 affected children investigated at one research center. Bone 2016;93:125-138.

41. Wallgren-Pettersson C, Clarke A, Samson F, et al. The myotubular myopathies: differential diagnosis of the $\mathrm{X}$ linked recessive, autosomal dominant, and autosoma recessive forms and present state of DNA studies. J Med Genet 1995;32:673-679.

42. Neto OA, Silva MRE, Martins CD, et al. A study of a cohort of X-linked myotubular myopathy at the clinical, histologic, and genetic levels. Pediatr Neurol 2016;58: 107-112.

43. Laporte J, Kress W, Mandel JL. Diagnosis of X-linked myotubular myopathy by detection of myotubularin. Ann Neurol 2001;50:42-46.

44. Laporte J, Biancalana V, Tanner SM, et al. MTM1 mutations in X-linked myotubular myopathy. Hum Mutat 2000;15:393-409.

45. Pierson CR, Dulin-Smith AN, Durban AN, et al. Modeling the human MTM1 p.R69C mutation in murine Mtm1 results in exon 4 skipping and a less severe myotubular myopathy phenotype. Hum Mol Genet 2012;21:811-825

46. Smith BK, Renno MS, Martin AD, Corti M, Byrne BJ. Reply: respiratory motor function in centronuclear myopathy. Muscle Nerve 2016;53:660-661.

47. Mack DL, Poulard K, Goddard MA, et al. Systemic AAV8-mediated gene therapy drives whole-body correction of myotubular myopathy in dogs. Mol Ther 2017;25 839-854

48. Leborgne C, Latournerie V, Boutin S, et al. Prevalence and long-term monitoring of humoral immunity against adeno-associated virus in Duchenne Muscular Dystrophy patients. Cell Immunol Epub 2018 Mar 16.

49. Robb SA, Sewry CA, Dowling JJ, et al. Impaired neuromuscular transmission and response to acetylcholinesterase inhibitors in centronuclear myopathies. Neuromuscul Disord 2011;21:379-386.

50. Dowling JJ, Joubert R, Low SE, et al. Myotubular myopathy and the neuromuscular junction: a novel therapeutic approach from mouse models. Dis Model Mech 2012;5 852-859. 